\title{
Characteristic Relationship of Lung Tb Laboratory Officer Puskesmas With Error Rate Results of Sputum Examination Suspected Pulmonary Tb In Kudus Regency
}

Retno Purbosari

Department of Public Health Sciences, Faculty of Sports Science, Semarang State University

\section{ARTICLE INFO}

Keywords:

Error rate, laboratory office, Pulmonary TB, Puskesmas
E-mail:

retnopurbo19@gmail.com

\section{ABSTRACT}

The problem studied in this study is whether there is a relationship between the characteristics of lung TB laboratory officers at puskesmas with the error rate of sputum examination results suspected pulmonary $\mathrm{TB}$ in Kudus Regency. The purpose of this study is to find out the relationship between the characteristics of lung TB laboratory officers at puskesmas with the error rate of sputum examination results suspected pulmonary TB in KudusRegency.This type of research is explanatory research with a cross sectional approach. The free variables in the study were educational background, training, knowledge of direct microscopic sputum examination, staffing status, working life and workload while the bound variables were error rates. The population and samples in this study were all officers of the Tb Pulmonary Health Center laboratory in Kudus Regency numbered 21 people. The instrument used is a questionnaire. Primary data is obtained through interviews. Secondary data is obtained from data in the Holy District Health Office. The data obtained is processed using the chi square test with a meaningful level $(\alpha)$ of 0.05 . Based on the results of the study obtained that the characteristics of officers related to the error rate are training $(\mathrm{p}=0.012, \mathrm{CC}=0.506)$, knowledge of direct microscopic examination of sputum ( $\mathrm{p}$ $=0.004, \mathrm{CC}=0.594)$, staffing status $(\mathrm{p}=0.025, \mathrm{CC}=$ $0.484)$, working period $(\mathrm{p}=0.004, \mathrm{CC}=0.594)$, and workload $(\mathrm{p}=0.025, \mathrm{CC}=0.484)$. Based on the results of the research advice submitted is that training should be given to all tb laboratory officers of The Puskesmas lung on a regular basis every year because training is one of the efforts to improve the quality of human resources in terms of knowledge, attitudes and skills.

Copyright (C) 2021 Eduhealth Journal.All rights reserved. is Licensed under a Creative Commons AttributionNonCommercial 4.0 International License (CC BY-NC

4.0)

\section{INTRODUCTION}

Health development as one of the national development efforts is directed at achieving awareness, willingness and ability to live a healthy life for every resident in order to achieve optimal health status.[1]. Health development goals can be successful if the morbidity and mortality rates can

The Correlation between the Characteristics of Pulmonary Tuberculosis Laboratory Officers at Puskesmas and the Error Rate of Sputum Examination Results of Lung TB Suspects in Kudus 
be reduced. Until now, the morbidity and mortality rates from infectious diseases are still quite high, one of which is tuberculosis[2].

Tuberculosis is a chronic infectious disease caused by the bacterium Mycobacterium tuberculosis[3]. These germs can attack all parts of the human body and the lungs $(90 \%)$. Tuberculosis is a health problem for Indonesia and the world. WHO states that about 1.9 billion people, one third of the world's population have been infected with tuberculosis germs. In the international world view, Indonesia is the largest contributor to pulmonary TB cases in the world after India and China. In Indonesia, pulmonary TB has re-emerged as the main cause of death after heart and respiratory disease. The results of the Household Health Survey (SKRT) show that tuberculosis is the number 3 cause of death after cardiovascular disease and number 1 of the infectious disease group. Until now this disease has not been completely cured, even on the contrary the number of new sufferers is increasing day by day[4].

It is estimated that 450,000 new TB cases are found every year, of which about $1 / 3$ of the patients are located around the Puskesmas, 1/3 are found in government and private hospitals/clinics, private practice and the rest are not reached by the Health Service Unit. Meanwhile, deaths due to TB are estimated at 175,000 per year. This TB disease attacks most of the productive working age group[5]. In Central Java, it is estimated that there were 100-150,000 sufferers in 1990-1997. Although the incidence rate tends to decrease, new sufferers show an increase of up to $4 \%$, which is 110 out of every 100,000 population or 33,000 people every year.

Starting in 1995 the Pulmonary TB Disease Eradication Program (P2TB) implemented the DOTS (Directly Observed Treatment Shortcourse) strategy which was implemented in stages[6]. In the context of the successful implementation of the Pulmonary P2TB program, the priority is aimed at improving the quality of services and using rational treatment. In eradicating pulmonary TB disease, the government in this case the Ministry of Health uses Puskesmas as the spearhead to break the chain of transmission of pulmonary TB disease in the community, namely by finding and treating patients until they recover, so treatment is given free of charge at the Government Health Service Unit (UPK), especially Public health center[7]. One of the services provided at the Puskesmas to patients with pulmonary $\mathrm{TB}$ is a laboratory examination. In the pulmonary TB control program, microscopic examination of smears from sputum specimens is a key component for establishing the diagnosis and evaluation and follow-up of treatment.[8]. Microscopic examination of sputum is the most efficient, easy and inexpensive sputum examination. Microscopic examination is specific and quite sensitive because the examination of 3 specimens (During the Morning Time / SPS) of sputum microscopically is directly identical in value to the examination of sputum by culture or culture.

One of the problems that are still encountered in the implementation of the Pulmonary P2TB program is that the quality of sputum examination is not fully guaranteed evenly. Inability to interpret laboratory tests optimally can interfere with patient care and inappropriate use of laboratories can interfere with diagnosis[9]. To ensure the accuracy and accuracy of the results of direct microscopic examination of sputum, laboratory quality assurance activities must be carried out. Laboratory quality stabilization activities to monitor the quality of the management of Puskesmas laboratory examinations are carried out through cross checks or cross tests, namely sending one preparation from all slides of AFB + each suspect patient plus 10\% BTA - the results of the Puskesmas examination are taken randomly to the Health Laboratory Center (BLK) or designated BP4[10]. The error rate (laboratory error rate) obtained from the results of the cross check is one indicator of the pulmonary TB control program. According to $\mathrm{WHO}$, if the error rate is $5 \%$, the quality of the sputum examination in the district or city is considered good. By carrying out a cross check of specimens, the quality of the results of examination of sputum preparations at the health center concerned can be known. The accuracy of the examination of this specimen is very important because it involves the accuracy of the diagnosis in the suspect patient. If the laboratory error rate (error rate) from the cross check results is known to be $>5 \%$, it can have an impact on the results of specimen readings which in the end will result in medication errors in patients so that it can interfere with the pulmonary TB disease control program.

The Correlation between the Characteristics of Pulmonary Tuberculosis Laboratory Officers at Puskesmas and the Error Rate of Sputum Examination Results of Lung TB Suspects in Kudus 
Kudus Regency has 19 Puskesmas in its working area. According to the results of the Pulmonary P2TB program activities from 1999 to 2005 the error rate (laboratory error rate) was still above $5 \%$, which was around $10-15 \%$, while the results of the Pulmonary P2TB program in the first quarter still showed a high reading error of $13.6 \%$., this causes the error rate in Kudus Regency to be ranked 1 in Central Java. The results of this cross check must be followed up. If the cross check results show an error rate of more than $5 \%$, the relevant units must further investigate what the possible causes are. The error rate achievement rate can be influenced by several factors, one of the influencing factors is pulmonary TB laboratory personnel, because these laboratory workers have different individual characteristics.[11]. According to Yamoto's research, these characteristics include age, gender, educational background, training, eye health, employment status and length of work.[12]. Meanwhile, according to Sri Retno Rindjaswati's research, internal characteristics include age, gender, education level, length of work and external characteristics, including dual work, funding, awards, training, binocular microscope, Ziehl Neelsen reagent and glass slides.[13].

\section{METHOD}

The independent variables in this study were educational background, training, knowledge of direct microscopic sputum examination, employment status, years of service and workload. The dependent variable is the error rate of sputum examination results. Confounding variables in this study are:

1) Age was controlled by selecting respondents aged between $15-55$ years because they were classified as productive age.

2) Gender is assumed to be the same because in the laboratory examination of pulmonary TB, it is relatively not using heavy physical exertion so that between men and women have the same opportunity.

3) Lighting is controlled by selecting respondents who use natural lighting (sunlight) or a lamp of at least 40 watts.

4) The microscope, Ziehl Neelsen reagent and sputum pot were assumed to be the same because they were obtained directly from the Health Service.

5) Sputum and sputum collection are assumed to be the same because based on an initial survey from the Health Office, it was shown that sputum and sputum collection carried out by laboratory personnel had met the requirements.

Operational definition:

Table 1. Operational Definition and Variable Measurement Scale

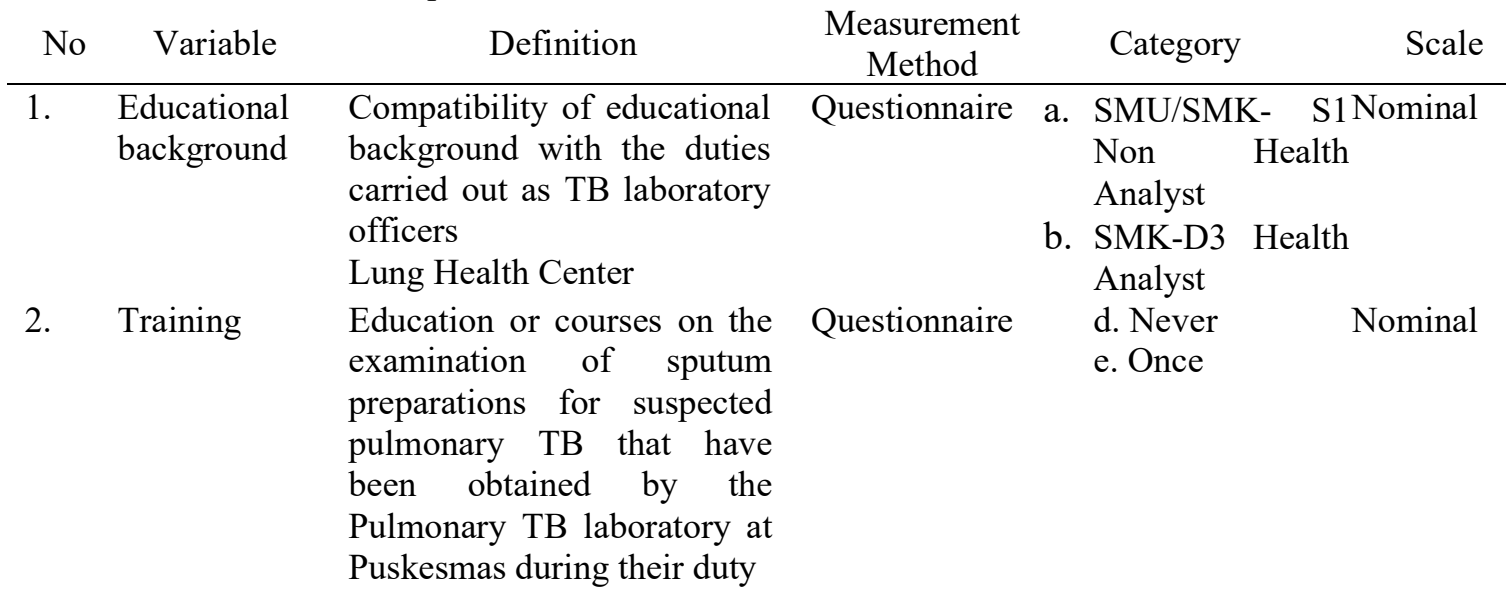

The Correlation between the Characteristics of Pulmonary Tuberculosis Laboratory Officers at Puskesmas and the Error Rate of Sputum Examination Results of Lung TB Suspects in Kudus 
3. Knowledge of The number of scores Interview

direct microscopic examination of sputum

4. Employment status obtained which shows the knowledge of pulmonary TB laboratory workers at the Puskesmas regarding direct microscopic examination of sputum includes:

-Sputum retrieval (questions no. 1, 2)

-Making write-off preparations (question no. 3) Status of laborato
personnel in employment

5. Years service

of The period of time or length of work as a Pulmonary TB laboratory officer at the Health Center stated in years

6. Workload The average number of sputum slides for suspected pulmonary TB examined by the Pulmonary TB laboratory staff at the Puskesmas

7. Error The number of laboratory ratespu errors produced by those tum test obtained from the report data results on the results of the $\mathrm{P} 2 \mathrm{~TB}$ Lung activities

Questionnaire$$
\text { Questionnaire }
$$

Questionnaire

Questionnaire
a. Less, checking $<10$ slides per day
b. Ok, if you check 10-20 slides per day

Questionnaire
a. Bad, if error rateordinal $>5 \%$
b. $\mathrm{OK}$, if the error
rate $5 \%$

$$
\begin{aligned}
& \text { b. Medium, 6-10 } \\
& \text { years }
\end{aligned}
$$$$
\text { c. Old, }>10 \text { years }
$$
Honorary
Nominal employees

The population in this study were all pulmonary TB laboratory workers at the Puskesmas who performed microscopic examination of sputum preparations in the Kudus Regency area, as many as 21 laboratory officers. The sample taken was the entire population, namely all laboratory workers for pulmonary TB at the Puskesmas who carried out microscopic examination of sputum preparations in the Kudus Regency area, namely as many as 21 laboratory officers.

Based on the results of the reliability calculation, it was obtained that the alpha value for the questionnaire item regarding knowledge about microscopic examination of sputum was directly declared valid, namely 0.874 because at a significant level of $5 \%$ with $n=15$, an $r$ table of 0.514 was obtained. Thus, all question items on the questionnaire regarding knowledge of microscopic sputum examination were immediately declared valid and reliable to use because $r$ count $>\mathrm{r}$ table.

Primary data in the form of data on educational background, training, knowledge of direct microscopic examination of sputum, employment status, years of service and workload of pulmonary TB laboratory workers at Puskesmas. The data taken are general data taken from the Health Profile of Kudus Regency and data from the P2 TB Pulmonary Program activities in Kudus Regency, especially data from cross-check results of sputum preparation.

\section{RESULT AND DISCUSSION}

Improvement of health facilities is needed as an effort to improve the welfare of the community. Apart from the government, the role of the private sector in supporting health facilities is also quite high.

Table 2. Number of Community Health Centers by District in Kudus Regency

The Correlation between the Characteristics of Pulmonary Tuberculosis Laboratory Officers at Puskesmas and the Error Rate of Sputum Examination Results of Lung TB Suspects in Kudus 


\begin{tabular}{llccccc} 
No & districts & $\begin{array}{c}\text { Public } \\
\text { health } \\
\text { center }\end{array}$ & $\begin{array}{l}\text { Auxiliary } \\
\text { Health } \\
\text { Center }\end{array}$ & $\begin{array}{l}\text { Nursing } \\
\text { Center }\end{array}$ & $\begin{array}{l}\text { Mobile } \\
\text { Health } \\
\text { Center }\end{array}$ & $\begin{array}{l}\text { Medical } \\
\text { Center }\end{array}$ \\
\hline 1 & Kaliwungu & 2 & 3 & 0 & 2 & 0 \\
2 & City & 3 & 5 & 0 & 3 & 8 \\
3 & teak & 2 & 4 & 0 & 2 & 1 \\
4 & invitation & 2 & 3 & 1 & 2 & 2 \\
5 & Mejobo & 2 & 4 & 1 & 2 & 2 \\
6 & Jekulo & 2 & 8 & 1 & 2 & 1 \\
7 & Bae & 2 & 4 & 0 & 2 & 1 \\
8 & stupid & 2 & 6 & 1 & 2 & 1 \\
9 & Dawe & 2 & 6 & 1 & 2 & 0 \\
\hline & Amount & 19 & 43 & 5 & 19 & 16
\end{tabular}

The health status of a community cannot be separated from the morbidity and mortality rates. Secondary data taken from the Health Office of Kudus Regency obtained the following proportions of disease:

\begin{tabular}{llcl}
\multicolumn{4}{c}{ Table 3 Proportion of Diseases in Kudus Regency } \\
Nope of disease & Amount & Percentage (\%) \\
\hline 1. & ARI & 76,154 & 38.83 \\
2. & Disorders of the muscular system & 28,154 & 13.98 \\
3. & Other diseases of lower respiratory & 11,640 & 5.78 \\
4. & Diarrhea & 11,616 & 5.77 \\
5. & Hypertension and Cardiovascular & 11,606 & 5.76 \\
6. & Anemia & 11,308 & 5.62 \\
7. & Other viral diseases & 10,197 & 5.06 \\
8. & Gastritis & 8097 & 4 \\
9. & Dental caries & 6.897 & 3.43 \\
10. & Pharyngitis & 5.297 & 2.63 \\
11. & Diabetes mellitus & 4,555 & 2.26 \\
12. & Skin infections & 4.205 & 2.09 \\
13. & Asthma & 3.918 & 1.95 \\
14. & clinical pulmonary TB & 3,814 & 1.9 \\
15. & Skin disease due to allergies & 3.803 & 1.89 \\
\hline & Total & 201.261 & 100
\end{tabular}

The distribution of the frequency of respondents based on educational background can be seen that most of the respondents have an educational background of SMU/SMK-S1 Non-Health Analyst with a percentage of $52.4 \%$. The frequency distribution of respondents based on training can be seen that most of the respondents have attended training with a percentage of $52.4 \%$. The frequency distribution of respondents based on knowledge can be seen that most of the respondents have sufficient knowledge with a percentage of $52.4 \%$. The frequency distribution of respondents based on employment status can be seen that most of the respondents have civil servant status with a percentage of $66.7 \%$. The frequency distribution of respondents based on years of service can be seen that most of the respondents have medium tenure of 6-10 years with a percentage of $47.6 \%$.

\subsection{Bivariate Analysis Results}

The results of the cross tabulation calculation of the relationship between educational background and the error rate can be seen in the table, as follows:

Table 4 Cross-tabulation of Educational Background with Error Rate Error rate

\begin{tabular}{ccccrrrr}
\multicolumn{1}{c}{ Educational background } & \multicolumn{2}{c}{ Bad } & \multicolumn{2}{c}{ Well } & \multicolumn{2}{c}{ Total } & P value \\
& $\square$ & $\%$ & $\square$ & $\%$ & $\square$ & $\%$ \\
\hline SMU/SMK-S1 Non Health Analyst & 4 & 36.4 & 7 & 63.6 & 11 & 100 & 0.311
\end{tabular}

The Correlation between the Characteristics of Pulmonary Tuberculosis Laboratory Officers at Puskesmas and the Error Rate of Sputum Examination Results of Lung TB Suspects in Kudus 


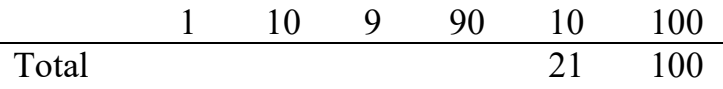

The table above shows that respondents who have an educational background of SMU/SMK-S1 Non Health Analysts where $36.4 \%$ get a bad error rate and $63.6 \%$ get a good error rate, while respondents who have an educational background of SMK-D3 Health Analysts where 10\% get a bad error rate and $90 \%$ get a good error rate. Based on the Fisher test, it was found that the $p$ value was greater than $0.05(0.311>0.05)$, which means that there is no significant relationship between the educational background of the Pulmonary TB laboratory workers at Puskesmas and the error rate of sputum examination results for suspected pulmonary TB in Kudus Regency.

Table 5 Cross Tabulation of Training with Error Rate

\begin{tabular}{lllllllll}
\multicolumn{1}{c}{ Training } & \multicolumn{9}{c}{ Error rate } & \multicolumn{2}{c}{ Total } & P value \\
& $\sum$ & \multicolumn{1}{c}{ Well } & $\sum$ & $\%$ & $\sum$ & $\%$ & \\
\hline Not trained yet & 5 & 50 & 5 & 50 & 10 & 100 & 0.012 \\
Have you ever been trained? & 0 & 0 & 11 & 100 & 11 & 100 & \\
\hline Total & & & & 21 & 100 &
\end{tabular}

The table above shows that respondents who have not been trained where $50 \%$ get a bad error rate and $50 \%$ get a good error rate, while respondents who have been trained all get a good error rate. This shows that the training also determines the good or bad error rate obtained. Based on Fisher's test, it was found that the $\mathrm{p}$ value was smaller than $0.05(0.012<0.05)$, which means that there is a significant relationship between the training of pulmonary TB laboratory workers at the Puskesmas with the error rate of sputum examination results for pulmonary TB suspects in Kudus Regency. Based on the calculation results also obtained a contingency coefficient of 0.506 . From these results, it can be explained that the close relationship between training and the error rate is 0.506 , which means it has a moderate level of relationship.

Table 6. Knowledge Cross Tabulation with Error Rate

\begin{tabular}{|c|c|c|c|c|c|c|c|}
\hline \multirow{2}{*}{ Knowledge } & \multicolumn{2}{|c|}{$\mathrm{Bad}$} & \multicolumn{2}{|c|}{$\begin{array}{c}\text { Error rate } \\
\text { Well }\end{array}$} & \multicolumn{2}{|c|}{ Total } & \multirow{2}{*}{$P$ value } \\
\hline & $\sum$ & $\%$ & $\sum$ & $\%$ & $\sum$ & $\%$ & \\
\hline Not enough & 4 & 80 & 1 & 20 & 5 & 100 & \\
\hline Enough & 1 & 9.1 & 10 & 90.9 & 11 & 100 & \\
\hline Well & 0 & 0 & 5 & 100 & 5 & 100 & \\
\hline & Tota & & & & 21 & 100 & \\
\hline
\end{tabular}

Based on the Fisher test, the results do not meet the requirements, then the categories are merged, for more details, it is shown in the following table:

Table 7. Knowledge Cross Tabulation (Category Merging) with Error Rate

\begin{tabular}{lccccccc}
\multicolumn{1}{c}{ Knowledge } & \multicolumn{9}{c}{ Bad } & \multicolumn{2}{c}{ Well } & \multicolumn{2}{c}{ Total } & P value \\
& $\sum$ & $\%$ & $\sum$ & $\%$ & $\sum$ & $\%$ & \\
\hline Not enough & 4 & 80 & 1 & 20 & 5 & 100 & 0.004 \\
Pretty good & 1 & 6.3 & 15 & 93.8 & 16 & 100 & \\
\hline & Total & & & & 21 & 100 &
\end{tabular}

The table above shows that respondents who have less knowledge, where $80 \%$ get a bad error rate and $20 \%$ get a good error rate, while respondents who have good enough knowledge where $6.3 \%$ get a bad error rate and $93.8 \%$ get an error rate good. Based on Fisher's test, it was found that the $p$ value was smaller than $0.05(0.004<0.05)$, which means that there is a significant relationship between the knowledge of the pulmonary TB laboratory workers at the Puskesmas and the error rate of the sputum examination results for pulmonary TB suspects in Kudus Regency. Based on the calculation results also obtained a contingency coefficient of 0.594 . From these results it can be explained that the close relationship between knowledge and error rate is 0.594 , which means it has a moderate level of relationship.

The Correlation between the Characteristics of Pulmonary Tuberculosis Laboratory Officers at Puskesmas and the Error Rate of Sputum Examination Results of Lung TB Suspects in Kudus 
Table 8. Cross Tabulation of Employment Status with Error Rate

\begin{tabular}{|c|c|c|c|c|c|c|c|}
\hline \multirow[t]{2}{*}{ Employment status } & \multicolumn{6}{|c|}{ Error rate } & \multirow[t]{2}{*}{$P$ value } \\
\hline & $\sum$ & $\%$ & $\Sigma$ & $\%$ & $\sum$ & $\%$ & \\
\hline Honorary & 4 & 57.1 & 3 & 42.9 & 7 & 100 & 0.025 \\
\hline civil servant & 1 & 7.1 & 13 & 92.9 & 14 & 100 & \\
\hline
\end{tabular}

The results of the cross tabulation calculation of the relationship between employment status and error rate show that respondents who have honorary employment status, where $57.1 \%$ get a bad error rate and $42.9 \%$ get a good error rate, while respondents who have civil servant status where 7.1 $\%$ got a bad error rate and $92.9 \%$ got a good error rate. Based on Fisher's test, it was found that the $p$ value was smaller than $0.05(0.025<0.05)$, which means that there is a significant relationship between the staffing status of the pulmonary TB laboratory workers at the Puskesmas with the error rate of sputum examination results for pulmonary TB suspects in Kudus Regency. Based on the calculation results also obtained a contingency coefficient of 0.484 . From these results it can be explained that the close relationship between employment status and an error rate of 0 ,

Based on the Fisher test, the results do not meet the requirements, then the categories are merged.

Table 9. Cross Tabulation of Working Periods (Category Merging) with Error Rate

\begin{tabular}{lccccccc}
\multirow{2}{*}{ Years of service } & \multicolumn{9}{c}{ Bad } & \multicolumn{2}{c}{ Well } & \multicolumn{2}{c}{ Total } & \multirow{2}{*}{ P value } \\
& $\sum$ & $\%$ & $\sum$ & $\%$ & $\sum$ & $\%$ & \\
\hline New & 4 & 80 & 1 & 20 & 5 & 100 & 0.004 \\
Medium-Long & 1 & 6.3 & 15 & 93.8 & 16 & 100 & \\
\hline & Total & & & & 21 & 100 &
\end{tabular}

The table above shows that respondents who have a new tenure where $80 \%$ get a bad error rate and $20 \%$ get a good error rate, while respondents who have a medium to long tenure, where $6.3 \%$ get a bad error rate and $93.8 \%$ get good error rate. Based on the Fisher test, it was found that the $\mathrm{p}$ value was smaller than $0.05(0.004<0.05)$, which means that there is a significant relationship between the working period of the pulmonary TB laboratory workers at the Puskesmas with the error rate of the sputum examination results for pulmonary TB suspects in Kudus Regency. Based on the calculation results also obtained a contingency coefficient of 0.594. From these results, it can be explained that the close relationship between tenure and error rate is 0.594 , which means it has a moderate level of relationship.

Table 10 Cross Tabulation of Workload with Error Rate

\begin{tabular}{lccccccc}
\multicolumn{1}{c}{ Workload } & \multicolumn{9}{c}{ Bad } & \multicolumn{2}{c}{ Well } & \multicolumn{2}{c}{ Total } & \multirow{2}{*}{ P value } \\
& $\sum$ & $\mathbf{\%}$ & $\sum$ & $\mathbf{\%}$ & $\sum$ & $\mathbf{\%}$ & \\
\hline Not enough & 4 & 57.1 & 3 & 42.9 & 7 & 100 & 0.025 \\
Well & 1 & 7.1 & 13 & 92.9 & 14 & 100 & \\
\hline & Total & & & & 21 & 100 &
\end{tabular}

The results of the cross tabulation calculation of the relationship between workload and error rate show that respondents who have a less workload where $57.1 \%$ get a bad error rate and $42.9 \%$ get a good error rate, while respondents who have a good workload are $7.1 \%$ get a bad error rate and $92.9 \%$ get a good error rate. Based on the Fisher test, it was found that the $\mathrm{p}$ value was smaller than $0.05(0.025<0.05)$, which means that there is a significant relationship between the workload of the pulmonary TB laboratory workers at the Puskesmas and the error rate of the sputum examination results for pulmonary TB suspects in Kudus Regency.

Based on the results of research on pulmonary TB laboratory workers at the Puskesmas in Kudus Regency, the results obtained from statistical analysis using the chi square test with a significance level $(\alpha)$ of 0.05 , can be seen in the table below:

The Correlation between the Characteristics of Pulmonary Tuberculosis Laboratory Officers at Puskesmas and the Error Rate of Sputum Examination Results of Lung TB Suspects in Kudus 
Table 11 Recapitulation of Bivariate Analysis Between Respondents' Characteristics and Error Rate

\begin{tabular}{clccl} 
No & Characteristics of Respondents & $\boldsymbol{P}$ value & $\boldsymbol{C C}$ & Information \\
\hline 1. & Educational background & 0.311 & 0.295 & Not significant \\
2. & Training & 0.012 & 0.506 & Significant \\
3. & Knowledge about inspectiondirect & 0.004 & 0.594 & Significant \\
& microscopic sputum & & & \\
4. & Employment status & 0.025 & 0.484 & Significant \\
5. & Years of service & 0.004 & 0.594 & Significant \\
6. & Workload & 0.025 & 0.484 & Significant
\end{tabular}

\subsection{Discussion}

In the pulmonary TB control program, the diagnosis is made by direct microscopic examination of sputum. Laboratory quality stabilization activities to monitor the quality of the management of Puskesmas laboratory examinations are carried out through cross checks or cross tests. The error rate (laboratory error rate) obtained from the results of the cross check is one of the indicators of the pulmonary TB control program. The laboratory error rate (error rate) can be influenced by several factors, one of the influencing factors is pulmonary TB laboratory personnel, because these laboratory workers have different individual characteristics.

Based on the results of the study, it showed that there was no relationship between the educational background of the pulmonary TB laboratory workers at the Puskesmas with the error rate of the sputum examination results for pulmonary TB suspects in Kudus Regency with a $p$ value of 0.311. Based on the results of the study, it showed that most of the respondents $(52.4 \%)$ had an education background of SMU/SMK-S1 Non-Health Analyst, while 47.6\% of respondents had an educational background of SMK-D3 Health Analyst. This is related to knowledge and ways of thinking so that they are able to produce something according to the level of education they have. Factors suspected to be the cause of educational background not related to the error rate are because most of the respondents have a medium working period (6-10 years),

Based on the results of the study, it showed that there was a relationship between the training of pulmonary TB laboratory workers at the Puskesmas with the error rate of sputum examination results for pulmonary TB suspects in Kudus Regency with a p value of 0.012 . Based on the results of the study showed that most of the respondents (52.4\%) had attended training, while $47.6 \%$ of respondents had never attended training. The results of the examination of preparations carried out by laboratory personnel who have received training tend to be more accurate than those who have never attended training. This is closely related to the skills of officers so that officers are able to work well, be skilled and produce inspection results with good quality.

The ability and skills of the examiners are determined, among other things, by training. Training is one of the efforts to improve the quality of human resources. Every laboratory staff needs to always improve their abilities and skills through continuous training both inside the laboratory and outside the laboratory. Job training is organized and directed to equip, improve and develop work skills or expertise in order to increase the ability, productivity and welfare of the workforce. Job training is organized based on a training program that refers to standard skills or expertise qualifications which are carried out in stages and continuously.

Based on the results of the study, it showed that there was a relationship between the knowledge of the pulmonary TB laboratory staff at the Puskesmas with the error rate of the sputum examination results for the suspect pulmonary TB in Kudus Regency with a p value of 0.004 . Based on the results of the study showed that most of the respondents $(76.2 \%)$ had good enough knowledge, while $23.8 \%$ of respondents had less knowledge. There is a relationship between the knowledge of pulmonary TB laboratory workers at the Puskesmas with the error rate. The knowledge possessed by a person will affect the way of thinking and acting. In the tuberculosis control program, the diagnosis is made by direct microscopic examination of sputum. The knowledge of direct microscopic sputum

The Correlation between the Characteristics of Pulmonary Tuberculosis Laboratory Officers at Puskesmas and the Error Rate of Sputum Examination Results of Lung TB Suspects in Kudus 
examination officers is very useful for laboratory workers in carrying out their work to obtain good quality examinations. Knowledge of what to know or important information is needed to perform daily tasks and information can provide a better understanding so as to solve problems that arise. With the knowledge possessed, it can have an impact on behavior which includes changes in habits or behavior.

Based on the results of the study, it was shown that there was a relationship between the employment status of the pulmonary TB laboratory workers at the Puskesmas with the error rate of the sputum examination results for pulmonary TB suspects in Kudus Regency with a p value of 0.025 . Based on the results of the study, it shows that most of the respondents $(66.7 \%)$ have civil servant status, while $33.3 \%$ of respondents have honorary employment status. The results of this study are in accordance with the opinion which states that the employment status of officers can affect the responsibilities of the tasks they carry out. This relates to clear sanctions for him. Civil servants are those who have met the requirements specified in the applicable laws and regulations.

Based on the results of the study, it was shown that there was a relationship between the working period of the pulmonary TB laboratory workers at the Puskesmas with the error rate of the sputum examination results for pulmonary TB suspects in Kudus Regency with a p value of 0.004 . Based on the results of the study, it showed that most of the respondents $(76.2 \%)$ had a medium-long tenure, while $23.8 \%$ of the respondents had a new tenure. This is closely related to the length of time the officer handles the job, so the longer he handles it tends to be more skilled. The period of work is closely related to the experiences gained in carrying out the task. Those who are experienced are seen as capable of carrying out their duties. The longer a person's working period, the better their skills will be because they have adapted to their work.

Based on the results of the study, it showed that there was a relationship between the workload of the pulmonary TB laboratory workers at the Puskesmas and the error rate of the sputum examination results for pulmonary TB suspects in Kudus Regency with a $p$ value of 0.025 . Based on the results of the study showed that most of the respondents $(66.7 \%)$ had a good workload, while $33.3 \%$ of respondents had a less workload. Workload is the amount of work done every day. It is recommended that Puskesmas TB laboratory staff examine 20 slides at most every day. The heavier the workload, the lower the concentration power of officers in carrying out their work. In order for laboratory personnel to maintain their skills (maintain the quality of examinations), he must have the opportunity to inspect 10-20 preparations every day.

\section{CONCLUSION}

Based on the results of the research conducted, it is concluded that:

1) There was no relationship between the educational background of pulmonary TB laboratory workers at Puskesmas and the error rate of sputum examination results for pulmonary TB suspects in Kudus Regency, $(\mathrm{p}=0.311)$.

2) There is a relationship between the training of pulmonary TB laboratory workers at Puskesmas and the error rate of sputum examination results for pulmonary TB suspects in Kudus Regency, $(\mathrm{p}=0.012)$.

3) There was a relationship between knowledge of direct microscopic sputum examination by laboratory workers for pulmonary $\mathrm{TB}$ at the Puskesmas with the error rate of sputum examination results for pulmonary TB suspects in Kudus Regency, $(p=0.004)$.

4) There is a relationship between the staffing status of pulmonary TB laboratory workers at Puskesmas with the error rate of sputum examination results for pulmonary TB suspects in Kudus Regency, $(p=0.025)$.

5) There was a relationship between the working period of the Pulmonary TB laboratory workers at the Puskesmas with the error rate of sputum examination results for pulmonary TB suspects in Kudus Regency, $(p=0.004)$.

6) There is a relationship between the workload of pulmonary TB laboratory workers at Puskesmas and the error rate of sputum examination results for pulmonary TB suspects in Kudus Regency, $(\mathrm{p}=0.025)$.

The Correlation between the Characteristics of Pulmonary Tuberculosis Laboratory Officers at Puskesmas and the Error Rate of Sputum Examination Results of Lung TB Suspects in Kudus 


\section{REFERENCES}

[1] S. Lardo, "STRATEGI PEMBANGUNAN KESEHATAN DAN KETAHANAN NASIONAL DALAM PERSPEKTIF DAYA JUANG BANGSA," J. Pertahanan Bela Negara, vol. 10, no. 1, 2020, doi: 10.33172/jpbh.v10i1.824.

[2] P. Hadisiwi and J. R. Suminar, "Literasi Kesehatan Masyarakat dalam Menopang Pembangunan Kesehatan Di Indonesia," Pros. Semin. Nas. Komun., 2016.

[3] N. K. A. DEWI, I. K. G. SUKARSA, and I. G. A. M. SRINADI, "FAKTOR-FAKTOR YANG MEMENGARUHI PENYEBARAN PENYAKIT TUBERKULOSIS (TBC) DI PROVINSI JAWA BARAT," E-Jurnal Mat., vol. 9, no. 3, 2020, doi: 10.24843/mtk.2020.v09.i03.p294.

[4] F. Rahman, Y. Priwahyuni, C. V. Gloria, I. Ikhtiyaruddin, and A. Chindyta, "CEGAH PENYAKIT TUBERKULOSIS DI PUSKESMAS HARAPAN RAYA KOTA PEKANBARU,” J. Pengabdi. Masy. Multidisiplin, vol. 4, no. 2, 2020, doi: 10.36341/jpm.v4i2.1188.

[5] I. Samhatul and W. Bambang, "Penanggulangan Tuberkulosis Paru dengan Strategi DOTS," Higeia J Public Heal Res Dev, vol. 3, no. 2, 2019.

[6] S. Inayah and B. Wahyono, "Penanggulangan Tuberkulosis Paru dengan Strategi DOTS," Higeia J Public Heal Res Dev, vol. 3, no. 2, 2019.

[7] I. P. Lestari, L. Widagdo, and M. S. Adi, "Faktor-Faktor yang Berhubungan dengan Implementasi Program Pengendalian Tuberkulosis di Puskesmas Wilayah Kabupaten Magelang," J. Manaj. Kesehat. Indones., vol. 6, no. 2, 2018, doi: 10.14710/jmki.6.2.2018.114-120.

[8] A. R. Amelia, "Penyakit Menular Tuberkulosis Paru Di Wilayah Kerja Puskesmas Kaluku Bodoa Tahun 2019," Amelia, A. R. (2019). Penyakit Menular Tuberkulosis Paru Di Wil. Kerja Puskesmas Kaluku Bodoa Tahun 2019. 2, 26-27., vol. 2, 2019.

[9] A. R. Amelia, Nurbaeti, A. Baharuddin, and M. Y. Sari, "Hubungan Perilaku Keluarga Terhadap Penyakit Menular Tuberkulosis Paru Di Wilayah Kerja Puskesmas Kaluku Bodoa Tahun 2019," Sinergitas Multidisiplin Ilmu Pengetah. dan Teknol., vol. 2, 2019.

[10] P. K. Sucahya, "Barriers to Covid-19 RT-PCR Testing in Indonesia: A Health Policy Perspective," $J$. Indones. Heal. Policy Adm., vol. 5, no. 2, 2020, doi: 10.7454/ihpa.v5i2.3888.

[11] H. Hepiyansori and I. Tamimi, "HUBUNGAN PENGETAHUAN DAN SIKAP PETUGAS LABORATORIUM KESEHATAN TERHADAP PENGGUNAAN ALAT PELINDUNG DIRI," J. Ilm. Pharm., vol. 6, no. 1, 2019, doi: 10.52161/jiphar.v6i1.5.

[12] R. Afrilyani, . S., and R. Ginanjar, "GAMBARAN KEPATUHAN PETUGAS LABORATORIUM TERHADAP PENGGUNAAN ALAT PELINDUNG DIRI DI RUMAH SAKIT SALAK BOGOR TAHUN 2017," PROMOTOR, vol. 2, no. 4, 2019, doi: 10.32832/pro.v2i4.2244.

[13] P. Amalia, E. Kurniawan, I. G. Rahayu, and G. Noviar, "ANALISIS FAKTOR-FAKTOR KEPATUHAN PENERAPAN STANDAR OPERASIONAL PROSEDUR PENGAMBILAN DARAH VENA," J. Ris. Kesehat. Poltekkes Depkes Bandung, vol. 11, no. 2, 2019, doi: 10.34011/juriskesbdg.v11i2.751.

The Correlation between the Characteristics of Pulmonary Tuberculosis Laboratory Officers at

Puskesmas and the Error Rate of Sputum Examination Results of Lung TB Suspects in Kudus 